\title{
Desulfuribacillus alkaliarsenatis gen. nov. sp. nov., a deep-lineage, obligately anaerobic, dissimilatory sulfur and arsenate-reducing, haloalkaliphilic representative of the order Bacillales from soda lakes
}

\author{
D. Y. Sorokin $\cdot$ T. P. Tourova $\cdot$ M. V. Sukhacheva \\ G. Muyzer
}

Received: 10 February 2012 / Accepted: 3 May 2012 / Published online: 24 May 2012

(C) The Author(s) 2012. This article is published with open access at Springerlink.com

\begin{abstract}
An anaerobic enrichment culture inoculated with a sample of sediments from soda lakes of the Kulunda Steppe with elemental sulfur as electron acceptor and formate as electron donor at $\mathrm{pH} 10$ and moderate salinity inoculated with sediments from soda lakes in Kulunda Steppe (Altai, Russia) resulted in the domination of a Gram-positive, spore-forming bacterium strain AHT28. The isolate is an obligate anaerobe capable of respiratory growth using elemental sulfur, thiosulfate (incomplete reduction) and arsenate as electron acceptor with $\mathrm{H}_{2}$, formate, pyruvate and lactate as electron donor. Growth was
\end{abstract}

Communicated by A. Oren.

The GenBank/EMBL accession number of the 16S rRNA gene sequences of strain AHT28 $8^{\mathrm{T}}$ is HM046584.

Electronic supplementary material The online version of this article (doi:10.1007/s00792-012-0459-7) contains supplementary material, which is available to authorized users.

D. Y. Sorokin $(\bowtie) \cdot$ T. P. Tourova

Winogradsky Institute of Microbiology, Russian Academy

of Sciences, Prospect 60-let Octyabrya 7/2,

117811 Moscow, Russia

e-mail: soroc@inmi.ru; d.sorokin@tudelft.nl

D. Y. Sorokin · G. Muyzer

Environmental Biotechnology Group,

Department of Biotechnology, Delft University

of Technology, Delft, The Netherlands

M. V. Sukhacheva

Centre "Bioengineering", Russian Academy of Sciences,

Prospect 60-let Octyabrya 7/1, 117312 Moscow, Russia

G. Muyzer

Department of Aquatic Microbiology, Institute for Biodiversity and Ecosystem Dynamics, University of Amsterdam,

Amsterdam, The Netherlands possible within a $\mathrm{pH}$ range from 9 to 10.5 (optimum at $\mathrm{pH}$ 10) and a salt concentration at $\mathrm{pH} 10$ from 0.2 to $2 \mathrm{M}$ total $\mathrm{Na}^{+}$(optimum at $0.6 \mathrm{M}$ ). According to the phylogenetic analysis, strain AHT28 represents a deep independent lineage within the order Bacillales with a maximum of $90 \%$ 16S rRNA gene similarity to its closest cultured representatives. On the basis of its distinct phenotype and phylogeny, the novel haloalkaliphilic anaerobe is suggested as a new genus and species, Desulfuribacillus alkaliarsenatis (type strain AHT2 $8^{\mathrm{T}}=\mathrm{DSM} 24608^{\mathrm{T}}=\mathrm{UNIQEM}$ $\left.\mathrm{U} 855^{\mathrm{T}}\right)$.

Keywords Soda lakes $\cdot$ Sulfur-reducing ·

Arsenate-reducing $\cdot$ Haloalkaliphilic

\section{Introduction}

Our recent study on sulfidogenesis in anoxic sediments of hypersaline soda lakes in central Asia demonstrated a high activity of sulfur respiration even at soda-saturating conditions, in contrast to sulfate reduction (Sorokin et al. 2010). Our explanation for this is that at high $\mathrm{pH}$ the real substrate for sulfur respiration is linear soluble polysulfides $\mathrm{S}_{\mathrm{x}}^{2-}$ (Hedderich et al. 1999) which are formed due to a fast abiotic reaction between sulfide and elemental sulfur, and which are chemically stable at alkaline conditions. The use of polysulfides as substrate makes the whole process energetically much more favorable, because of the absence of the energy expensive sulfate activation step. Furthermore, sulfur respiration is energetically favored at high $\mathrm{pH}$ since protons are released.

So far, very little is known on the identity of sulfurrespiring prokaryotes functioning at high $\mathrm{pH}$ and high salt. Up to now, only two highly specialized haloalkaliphilic 
sulfur-reducing bacteria have been isolated from soda lakes. Moderately salt-tolerant isolates utilizing fatty acids as electron donor have been described as a novel genus and species Desulfurispira natronophila (Sorokin and Muyzer 2010), while an extremely natronophilic organism growing with $\mathrm{H}_{2}$, formate and acetate is a member of the order Halanaerobiales and described as a novel species $\mathrm{Na}$ troniella sulfidigena (Sorokin et al. 2011).

In this report, we describe the properties of a novel obligately anaerobic haloalkaliphilic bacterium isolated from Siberian soda lakes with a broader dissimilatory metabolism, which, apart from elemental sulfur, can also grow by arsenate reduction.

\section{Methods}

\section{Samples}

Sediment samples of the top $10 \mathrm{~cm}$ layer from six soda lakes in southern Kulunda Steppe (Altai, Russia, July 2009) were mixed in equal proportions to make a single inoculum used to enrich for sulfur-respiring haloalkaliphiles. The soda lakes had a $\mathrm{pH}$ range of 10.05-10.85, a salinity from 70 to $400 \mathrm{~g} \mathrm{l}^{-1}$, a soluble carbonate alkalinity from 0.8 to 4.7 $\mathrm{M}$, and the free sulfide content of the sediments from 0.28 to $3.17 \mathrm{mM}$ (Supplementary Table S1).

\section{Enrichment and cultivation}

Enrichment and routine cultivation of haloalkaliphilic anaerobes were performed at $28{ }^{\circ} \mathrm{C}$ on a mineral medium containing sodium carbonate buffer $\left(0.5 \mathrm{M} \mathrm{Na}^{+}\right)$with $\mathrm{pH}$ $10,0.1 \mathrm{M} \mathrm{NaCl}$, and $0.5 \mathrm{~g} \mathrm{l}^{-1}$ of $\mathrm{K}_{2} \mathrm{HPO}_{4}$. After sterilization in closed bottles, the medium was supplemented with $50 \mathrm{mM}$ formate as carbon and energy source, $1 \mathrm{mM}$ acetate as carbon source, $10 \mathrm{mg}^{-1}$ of yeast extract, $4 \mathrm{mM}$ $\mathrm{NH}_{4} \mathrm{Cl}, 1 \mathrm{mM} \mathrm{MgSO}, 1 \mathrm{ml} \mathrm{l}^{-1}$ each of an acidic trace metal solution and vitamin mix (Pfennig and Lippert 1966), and $1 \mathrm{ml} \mathrm{l}^{-1}$ of an alkaline Se/W solution (Plugge 2005). Elemental sulfur (Fluka) was autoclaved as a thick water paste at $110{ }^{\circ} \mathrm{C}$ for $40 \mathrm{~min}$ in closed bottles and added in excess of approximately $3 \mathrm{~g} \mathrm{l}^{-1}$. Other electron acceptors used were $\mathrm{KNO}_{3}$ and $\mathrm{Na}_{2} \mathrm{~S}_{2} \mathrm{O}_{3}$ (20 mM each), $\mathrm{KNO}_{2}$, $\mathrm{Na}_{2} \mathrm{SO}_{3}$, sodium selenate and selenite, sodium arsenate, DMSO (5 mM each), sodium fumarate $(20 \mathrm{mM})$, and freshly prepared amorphous ferrihydrite $(20 \mathrm{mM})$. The medium was dispensed into either Hungate tubes or serum bottles capped with butyl rubber stoppers and made anoxic by 5 cycles of flushing with argon gas-evacuation. In all cases, except for selenate, selenite and ferrihydrite, $1 \mathrm{mM}$ $\mathrm{HS}^{-}$was added to the medium as a reductant. Growth at micro-oxic conditions was tested with an oxygen concentration in the gas phase of $2 \%$. Routine cultivation was performed either in $15 \mathrm{ml}$ Hungate tubes with $10 \mathrm{ml}$ medium (soluble electron acceptors), or in $50 \mathrm{ml}$ serum bottles with $40 \mathrm{ml}$ medium with argon in the gas phase in case of sulfur and ferrihydrite. The $\mathrm{pH}$ dependence was examined at $\mathrm{Na}^{+}$content of $0.6 \mathrm{M}$, using the following filter-sterilized buffer systems: for $\mathrm{pH}$ 6-8, 0.1 M HEPES and $\mathrm{NaCl} / \mathrm{NaHCO}_{3}$; for $\mathrm{pH}$ 8.5-11, a mixture of sodium bicarbonate/sodium carbonate containing $0.1 \mathrm{M} \mathrm{NaCl}$. To study the influence of salt concentration on growth, sodium carbonate buffers at $\mathrm{pH} 10$ containing 0.1 and $3 \mathrm{M}$ of total $\mathrm{Na}^{+}$were mixed in different proportions.

\section{Analytical procedures}

Free sulfide and the sulfane atom of polysulfide were measured colorimetrically (Trüper and Schlegel 1964) after precipitation in $10 \%(\mathrm{w} / \mathrm{v}) \mathrm{Zn}$-acetate. The internal sulfur of the polysulfide was separated by acidification of the sample to $\mathrm{pH}<3$ with concentrated $\mathrm{HCl}$, precipitated by centrifugation, washed with distilled water, dried, extracted from the cell pellet with acetone and determined by cyanolysis (Sörbo 1957). Cell protein was determined according to Lowry et al. (1951) after removal of sulfide/ polysulfide and washing the cell pellet several times with $0.6 \mathrm{M} \mathrm{NaCl}$. Arsenite was detected by anionic chromatography after neutralization of the supernatant using Biotronic IC-1000 chromatograph (Germany), anionexchange column BT11AN, conductometer detector and $1 \mathrm{mM} \mathrm{Na} \mathrm{CO}_{3} / 1.2 \mathrm{mM} \mathrm{NaHCO}_{3}$ as eluent with a flow rate of $1.5 \mathrm{ml} \mathrm{min}-1$. Acetate was analyzed in the filtered supernatant after acidification to $\mathrm{pH} 4$ by anionic chromatography (Biotronic IC-1000; column BT III OS; conductivity detector; $1 \mathrm{mM} \mathrm{HCl}$ as eluent, $0.8 \mathrm{ml} \mathrm{min}^{-1}$ ). Phase-contrast microphotographs were obtained with a Zeiss Axioplan Imaging 2 microscope (Göttingen, Germany). For electron microscopy, the cells were negatively contrasted with $1 \%(\mathrm{w} / \mathrm{v})$ neutralized phosphotungstate and observed in JEOL 100 (Japan) transmission electron microscope. Polar lipids were extracted from $50 \mathrm{mg}$ of freeze-dried cells with acidic methanol and the fatty acid methyl esters were analyzed by GC-MS according to Zhilina et al. (1997). The cell wall fractionation and its peptidoglycan analysis were performed according to Streshinskaya et al. (1979). To analyze the respiratory quinones, the cells were extracted with cold acetone and the eluate was subjected to TLC (Collins 1985). A major UV-absorbing band was eluted and subjected to tandem mass spectrometry (LCG Advantage Max) with chemical ionization at atmospheric pressure and the quinones were identified by ionic mass. 
Genetic and phylogenetic analysis

The isolation of the DNA and determination of the $\mathrm{G}+\mathrm{C}$ content of the DNA was performed according to Marmur (1961) and Marmur and Doty (1962), respectively. For molecular analysis, the DNA was extracted from the cells using lysis in $1 \%(\mathrm{w} / \mathrm{v}) \mathrm{SDS} / 0.2 \mathrm{M} \mathrm{NaOH}$ at $60{ }^{\circ} \mathrm{C}$ and purified with the Wizard Preps Kit (Promega, USA). The nearly complete $16 \mathrm{~S}$ rRNA gene was obtained using general bacterial PCR primers $11 \mathrm{f}$ and 1492r (Lane 1991). The preliminary analysis of the new sequences was done with NCBI BLAST server (http://www.ncbi.nlm.nih.gov/ BLAST/) and RDP CLASSIFIER server (http://rdp.cme. msu.edu/classifier/classifier.jsp). The aarA gene (respiratory arsenate reductase subunit A) amplification was carried out with two primer sets: for a short fragment the pair aarAf/aarAr (Malasarn et al. 2004) and for a longer fragment-with the HAArrA-D1F/HAArrA-D1R pair (Kulp et al. 2006). The sequences were aligned with sequences from the GenBank using CLUSTAL W and the phylogenetic tree was reconstructed using neighbor-joining algorithm in the TREECONW program package (van de Peer and de Wachter 1994) and maximum-likelihood algorithm in PHYLIP 3.5c software (Felsenstein 1993).

\section{Results and discussion}

Enrichment and isolation of pure cultures

An anaerobic enrichment from soda lake sediments with formate as electron donor and sulfur as electron acceptor at $0.6 \mathrm{M}$ total $\mathrm{Na}^{+}$and $\mathrm{pH} 10$ resulted in a rapid formation of yellow polysulfide with total sulfane concentration reaching $12 \mathrm{mM}$ within 1 week. No growth was observed in control incubations lacking either formate or sulfur. The positive culture was dominated by slender, motile bend rods forming round terminal endospore (Fig. 1). The dominant phenotype was isolated in pure culture in a single round of serial dilutions and designated strain AHT28.

\section{Identification}

Phylogenetic analysis placed strain AHT28 into the order Bacillales as a deep independent lineage with a maximum of $90 \% 16 \mathrm{~S}$ rRNA gene sequence similarity to its nearest described species but without any obvious association with either of the families (Fig. 2). The closest sequences present in the GenBank belongs to an uncultured low GC Gram-positive bacterium, clone ML-S-9 (96 \% similarity), obtained from haloalkaline Mono Lake, in California, USA (Hollibaugh et al. 2006) and to two other uncultured bacteria (93-94\% similarity) from different habitats. The
RDP database query indicated $100 \%$ probability that the sequence belongs to the order Bacillales but did not place it in any known families of the order. Most probably, the strain and its close uncultured relatives represent a novel family but in our opinion more isolates are necessary to obtain to make a firm phenotypic assessment of this novel group of anaerobic bacilli.

The analysis of cellular fatty acids in polar lipids of strain AHT28 showed a lack of C15 components diagnostic for the low G + C Firmicutes (Kämpfer 2002), and a domination, instead, of $\mathrm{C} 16$ fatty acids. The same major components were detected in anaerobic alkaliphile $\mathrm{An}$ aerobacillus alkalilacustris (Zavarzina et al. 2009) obtained from a Siberian soda lake. In addition, strain AHT28 contained high concentrations of unsaturated C18 (Supplementary Table S2). Peptidoglycan analysis of the cell wall demonstrated a presence of meso-DAP, a typical marker of the order Bacillales (Schleifer and Kandler 1972), and the quinone analysis identified MK-7 as the major respiratory lipoquinone.

\section{Physiology}

Strain AHT28 is an obligate anaerobe with a respiratory metabolism restricted to the oxidation of a limited range of simple electron donors, such as $\mathrm{H}_{2}$, formate, pyruvate and lactate. Growth with hydrogen and formate was possible only in the presence of acetate as a carbon source (i.e. litho-heterotrophy). Among the tested electron acceptors, elemental sulfur, thiosulfate and arsenate can be used for growth with $\mathrm{H}_{2}$ and formate, while pyruvate and lactate could only be used with arsenate (Table 1). Growth with excess of elemental sulfur as the $e$-acceptor was accompanied by the accumulation of high concentrations of yellow polysulfide, which is a product of spontaneous reaction of the actual product $\mathrm{HS}^{-}$with the remaining sulfur stable at high $\mathrm{pH}$ (Fig. 3a). Reduction of thiosulfate was incomplete with formation of sulfide and sulfite (two-electron reduction, Fig. 3b). The fastest growth was observed with pyruvate as the $e$-donor and arsenate as the $e$-acceptor, whereby pyruvate was incompletely oxidized to acetate and arsenate reduced to arsenite (Fig. 3c). Same final products (acetate and arsenite) were accumulating during growth on lactate and arsenate. In case of pyruvate oxidation to acetate (3emoles), the theoretical stoichiometry of products is 1 acetate:1.5 arsenite, while it was less than 1 in the AHT28 cultures. In case of lactate, the real stoichiometry (1 acetate: 1 arsenite) was also much lower than the theoretical $4 e$-reduction ( 1 acetate: 2 arsenite). One of the possible explanations for this might be an excessive electron usage for anabolism, for example for the synthesis of organic compatible solutes. 
Fig. 1 Cell morphology of strain AHT28 grown at $\mathrm{pH} 10$ either with sulfur (a) or arsenate (b, c) as electron acceptor. a, b Phase-contrast microphotographs, c electron microphotograph of positively stained cells
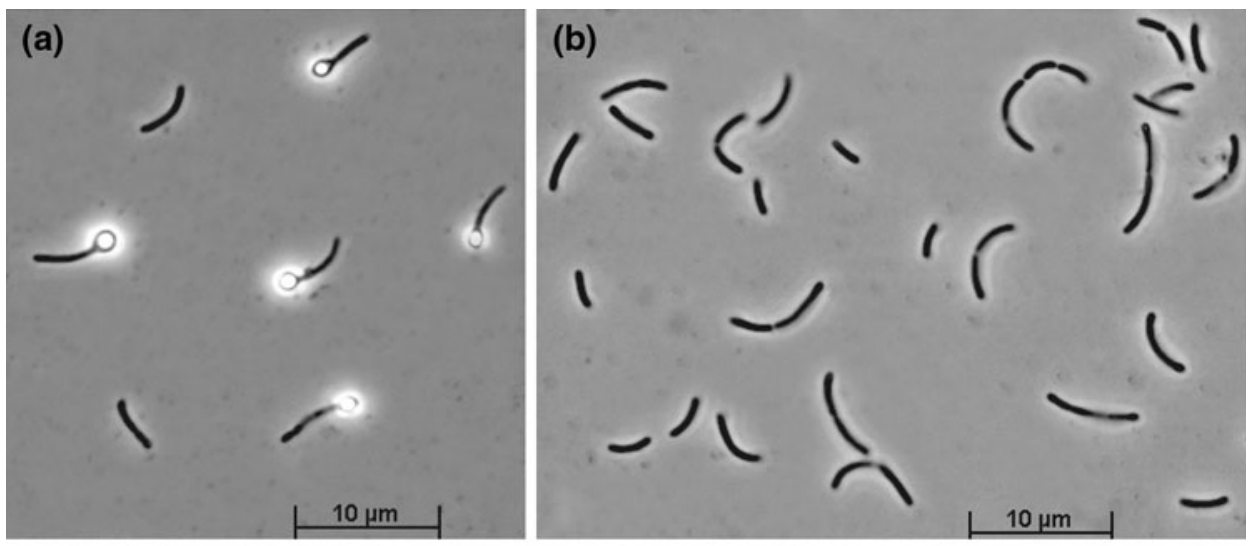

(c)
The organism displayed a high tolerance and activity of conversion of arsenic oxyanions, being able to grow at starting arsenate concentrations up to $40 \mathrm{mM}$, completely reducing it to arsenite in the presence of excess of $e$ donors, such as $\mathrm{H}_{2}$ or pyruvate. The biomass yield during growth with arsenate as $e$-acceptor was proportional to its starting concentration with three different $e$-donors tested indicating that arsenate served as the respiratory electron acceptor (Fig. 3d). This is also corroborated by the presence of the aarA gene in the genome of strain AHT28. Despite being a member of the order Bacillales, the AHT28 aarA is apparently not closely related to the corresponding gene of haloalkaliphilic Bacillus arseniciselenatis and B. selenatireducens (Fig. 4).

The differential expression of two pathways has also manifested in activity of washed cells pregrown with two different $e$-acceptors. Cells grown with sulfur most actively reduced sulfur and much less actively arsenate with formate as $e$-donor and vice versa with the exception when $\mathrm{H}_{2}$ served as $e$-donor. In that case both sulfur-grown and arsenate-grown cells had equally high specific sulfur-reducing activity (Table 2). The latter might indicate a link between sulfur (polysulfide) reductase and hydrogenase in the novel isolate. Finally, cells grown with formate and thiosulfate most actively reduced sulfur, less actively thiosulfate and had practically undetectable arsenate reductase activity (Table 2), which suggests that polysulfide reductase is responsible for both sulfur and thiosulfate reduction in AHT28.

None of the following electron acceptors can be utilized by strain AHT28 in the presence of formate or lactate as electron donor: nitrate, nitrite, selenate, selenite, ferrihydrite, colloidal $\mathrm{MnO}_{2}$, sulfate, sulfite, fumarate. None of the following electron donors in the presence of sulfur and arsenate were able to support growth: acetate, propionate, butyrate, malate, fumarate, succinate, $\mathrm{EtOH}, \mathrm{PrOH}, \mathrm{BuOH}$, glucose, fructose, xylose, yeast extract. 
Fig. 2 Phylogenetic position of the strain AHT28 within the order Bacillales based on $16 \mathrm{~S}$ rRNA gene sequence analysis. The phylogenetic outline of the order is according to Ludwig et al. (2009), where each branch represents a consensus from the sequences of several species in each genus. Tree topography and evolutionary distances are obtained by the neighborjoining method with Jukes and Cantor distances. Numbers at the nodes indicate the percentage of bootstrap values in 1000 replications (numbers in parenthesis indicate bootstrap values obtained by the alternative maximum-likelihood algorithm). Only values above $70 \%$ are included.

Multifurcations indicate that a common relative branching order was not significantly supported by the bootstrap analysis

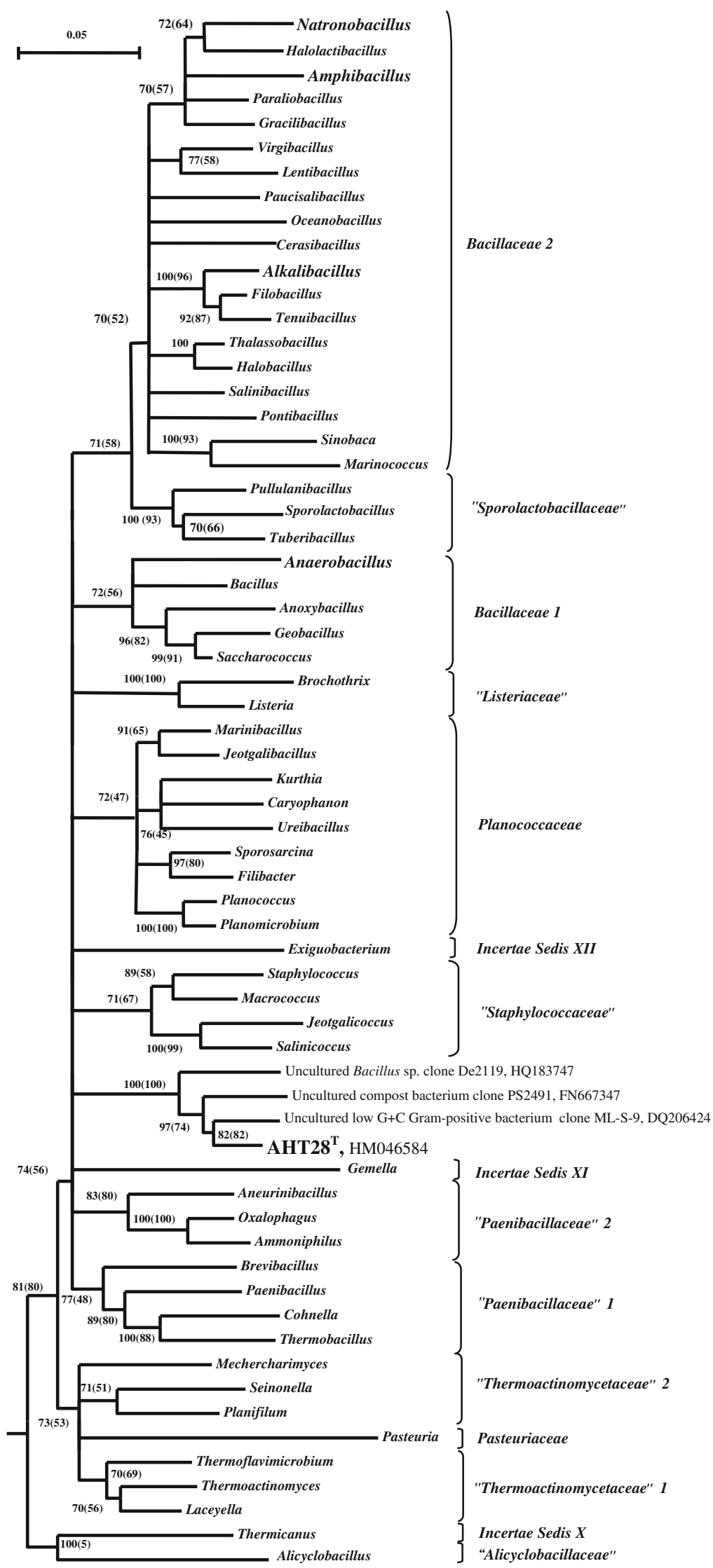


Arsenate might be present in relatively high concentrations in soda lakes due to mineral feeding from underground waters and evaporative concentration, as, for example, in Mono Lake and Searles Lake, wherein an active microbial dissimilatory arsenic cycle had been

Table 1 Growth of strain AHT28 by anaerobic respiration at $\mathrm{pH} 10$ and $0.6 \mathrm{M} \mathrm{Na}^{+}$

\begin{tabular}{llll}
\hline$e$-Donor & $e$-Acceptor & Final products & $\mu_{\max }\left(\mathrm{h}^{-1}\right)$ \\
\hline $\mathrm{H}_{2}$ & Sulfur & Polysulfide & 0.032 \\
& Thiosulfate & Sulfide + sulfite & nd \\
& Arsenate & Arsenite & 0.030 \\
Formate & Sulfur & Polysulfide & 0.055 \\
& Thiosulfate & Sulfide + sulfite & nd \\
& Arsenate & Arsenite & 0.058 \\
Pyruvate & Arsenate & Acetate + arsenite & 0.140 \\
Lactate & Arsenate & Acetate + arsenite & 0.078 \\
\hline
\end{tabular}

A
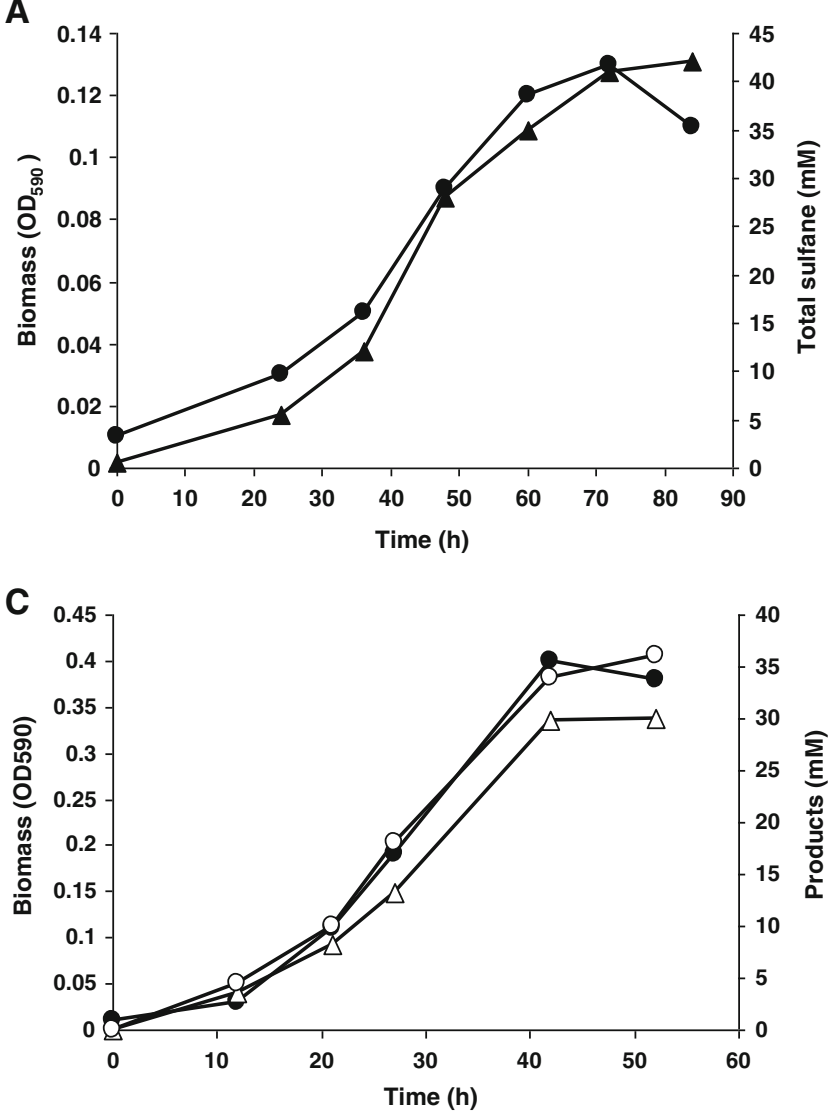

Fig. 3 Anaerobic growth dynamics of strain AHT28 at pH 10 and $0.6 \mathrm{M}$ total $\mathrm{Na}^{+}$. a Growth with $50 \mathrm{mM}$ formate $/ 2 \mathrm{mM}$ acetate and elemental sulfur (closed circles biomass, closed triangles total sulfane in polysulfide and sulfide). b Growth with $50 \mathrm{mM}$ formate $/ 2 \mathrm{mM}$ acetate and $10 \mathrm{mM}$ thiosulfate (closed circles biomass, open circles thiosulfate, closed triangles sulfide, open triangles sulfite). c Growth with $40 \mathrm{mM}$ pyruvate and $30 \mathrm{mM}$ arsenate (closed circles biomass, open circles arsenite, open triangles acetate). $\mathbf{d}$ Growth with arsenate demonstrated (Lloyd and Oremland 2006; Kulp et al. 2006, 2007). The dual capacity to grow by dissimilatory respiration of sulfur and arsenate in a haloalkaliphilic organism has only been reported once before for extremely halophilic and alkaliphilic representative of the order Halanaerobiales, Halarsenatibacter silvermanii, isolated from the hypersaline alkaline Searles Lake (Switzer Blum et al. 2009).

Influence of $\mathrm{pH}$ and sodium on the growth and activity of strain AHT28

Both with sulfur and arsenate as $e$-acceptors the growth was active at a $\mathrm{pH}$ above 8.5 and up to $10.5-10.6$, while the activity of washed cells had significantly broader $\mathrm{pH}$ range especially toward the lower pH limit (Fig. 5a). It is necessary to stress that in both cases (with arsenate and especially with sulfur) the $\mathrm{pH}$ changed significantly during growth and therefore the final $\mathrm{pH}$ values are presented in the graphs. In sodium
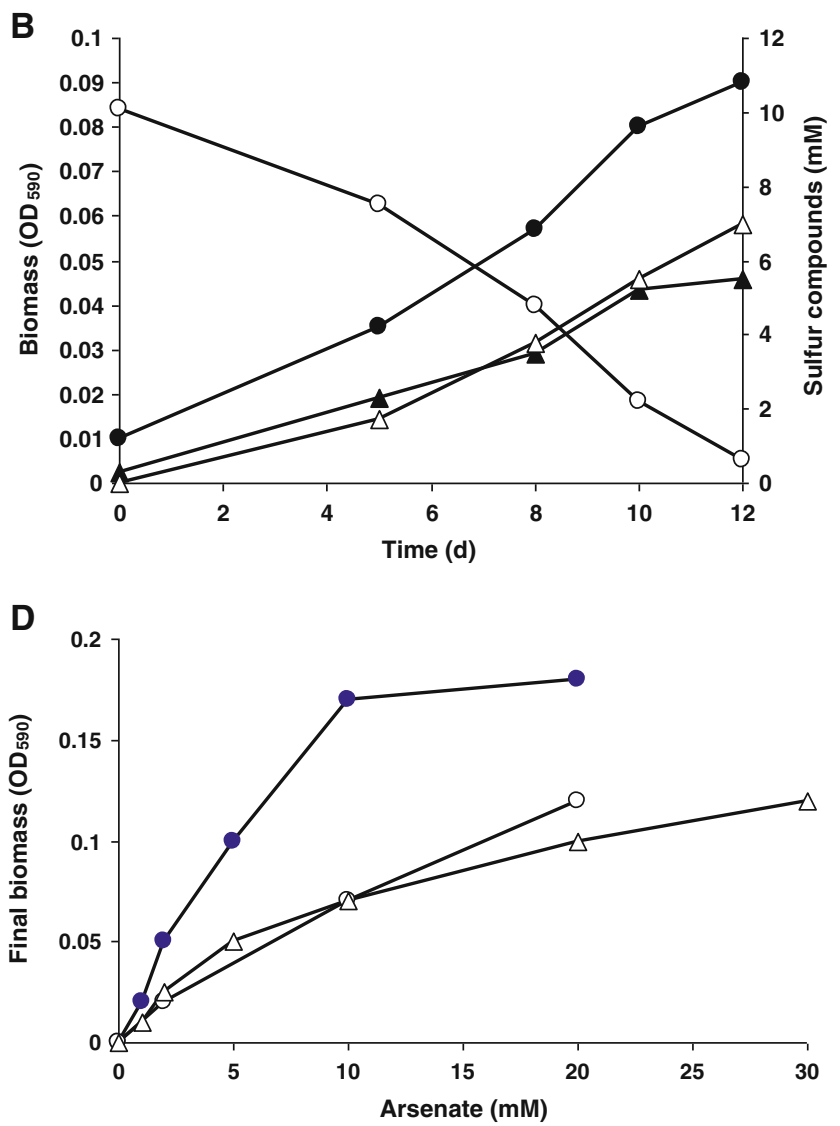

as $e$-acceptor: influence of arsenate concentration [closed circles with $20 \mathrm{mM}$ pyruvate (maximal accumulation of arsenite $=15 \mathrm{mM}$ ), open circles with $20 \mathrm{mM}$ lactate (maximal accumulation of arsenite $=20 \mathrm{mM}$ ), open triangles with $50 \mathrm{mM}$ formate (maximal accumulation of arsenite $=30 \mathrm{mM}$ )]. The data in the experiments $\mathrm{A}$ and $\mathrm{D}$ are average from two independent cultures, the data in the experiments $\mathrm{B}$ and $\mathrm{C}$ are from a single run 
Fig. 4 Phylogenetic position of strain AHT28 based on partial translated amino acid sequence of the aarA gene. Tree topography and evolutionary distances are obtained by the neighbor-joining method with Jukes and Cantor distances

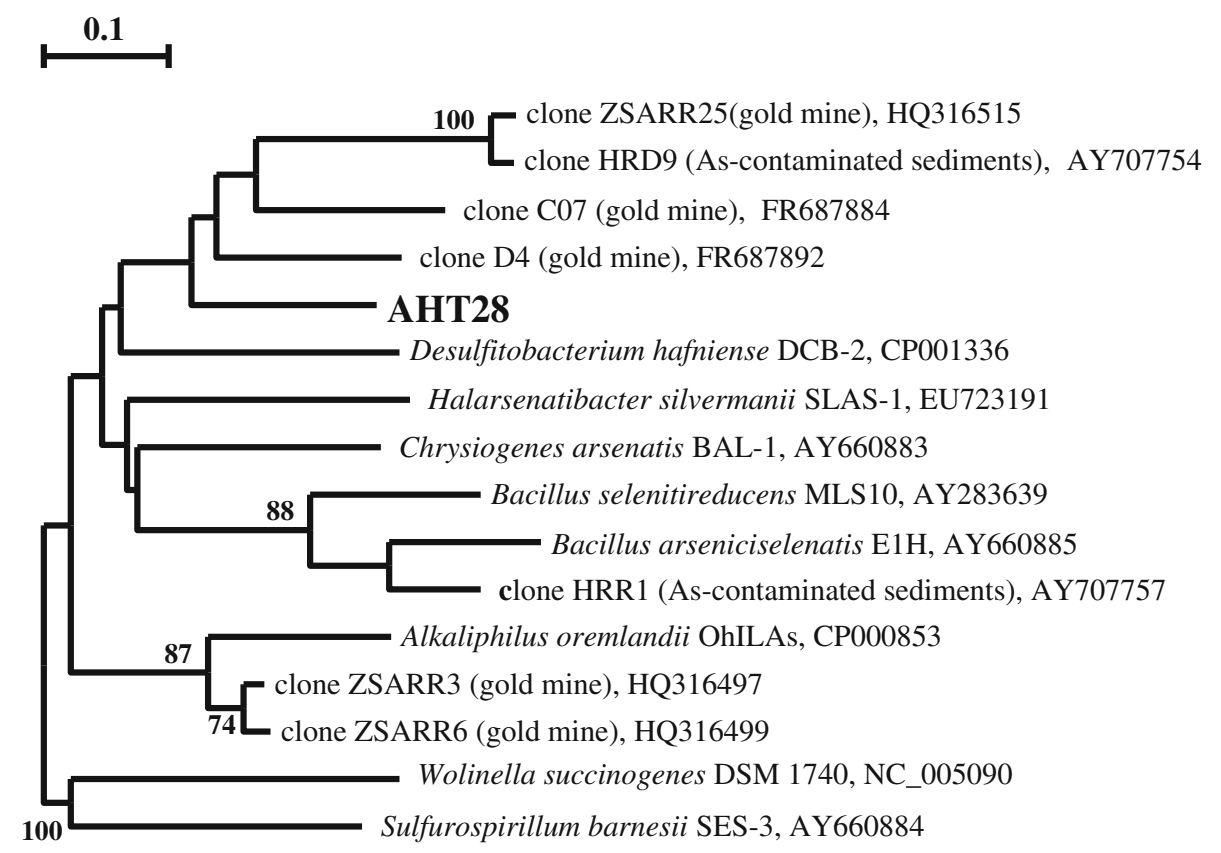

Table 2 Comparison of activity of washed cells of strain AHT28 grown with different $e$ acceptors at $\mathrm{pH} 10$ and $0.6 \mathrm{M}$ total $\mathrm{Na}^{+}$
$V s$ sulfur reduction, $V a$ arsenate reduction, $V t$ thiosulfate reduction [in nmol

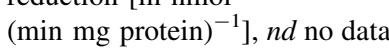

\begin{tabular}{|c|c|c|c|c|c|c|c|c|}
\hline \multirow[t]{2}{*}{$e$-Donor } & \multirow[t]{2}{*}{$e$-Acceptor } & \multicolumn{2}{|c|}{$\begin{array}{l}\text { Cells grown: } \\
\text { formate }+ \text { sulfur }\end{array}$} & \multicolumn{2}{|c|}{$\begin{array}{l}\text { Cells grown: } \\
\text { pyruvate }+ \text { arsenate }\end{array}$} & \multicolumn{3}{|c|}{$\begin{array}{l}\text { Cells grown: } \\
\text { formate }+ \text { thiosulfate }\end{array}$} \\
\hline & & Vs & $\mathrm{Va}$ & Vs & $\mathrm{Va}$ & Vs & $\mathrm{Va}$ & $\mathrm{Vt}$ \\
\hline Formate & Sulfur & 50 & & 4 & & 52 & & \\
\hline $\mathrm{H}_{2}$ & & 40 & & 48 & & 40 & & \\
\hline Pyruvate & & 4 & & 8 & & nd & & \\
\hline Formate & Arsenate & & 13 & & 3 & & 1 & \\
\hline $\mathrm{H}_{2}$ & & & 9 & & 50 & & 0.5 & \\
\hline Pyruvate & & & 2 & & 30 & & nd & \\
\hline Formate & Thiosulfate & & & & & & & 12 \\
\hline $\mathrm{H}_{2}$ & & & & & & & & 9 \\
\hline Pyruvate & & & & & & & & 0 \\
\hline
\end{tabular}

A

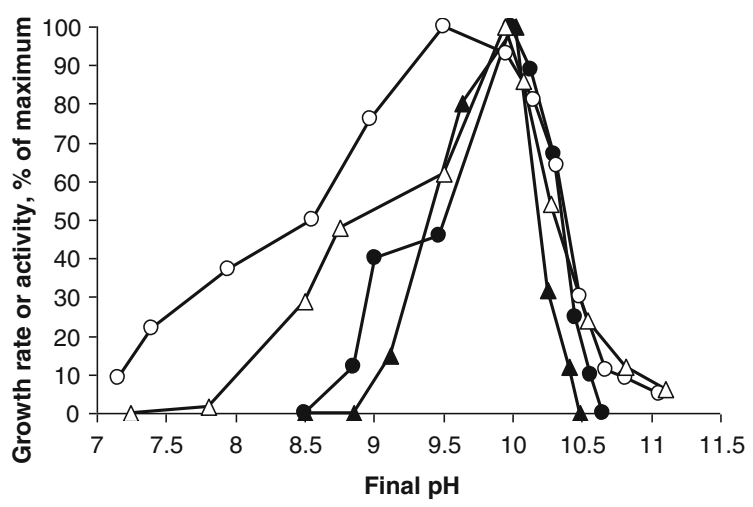

Fig. 5 Influence of $\mathrm{pH}$ at $0.6 \mathrm{M} \mathrm{Na}^{+}$(a) and sodium carbonates at $\mathrm{pH} 10$ (b) on anaerobic growth (closed symbols) and anaerobic respiratory activity of washed cells (opened symbols) of strain AHT28. Circles growth or respiratory activity with pyruvate as $e$ -
B

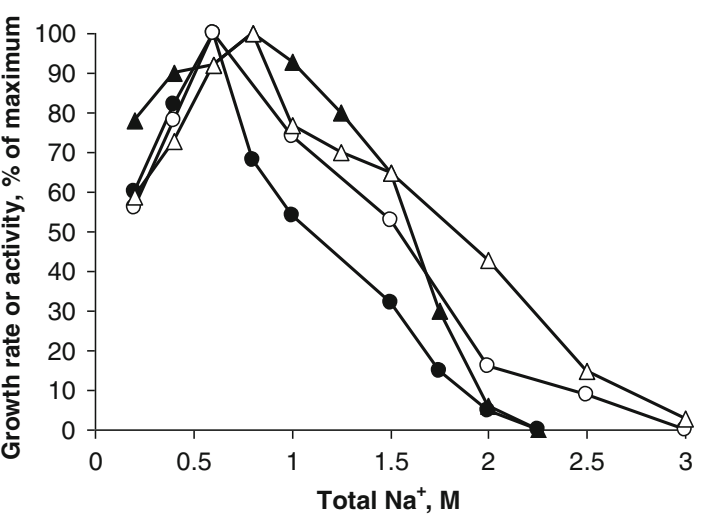

donor and arsenate as $e$-acceptor, triangles growth or activity with formate as $e$-donor and sulfur as e-acceptor. The data represent mean values obtained in two-three replicates with a deviation ranged from 3 to $12 \%$ 
Table 3 Phenotypic comparison of strain AHT28 with anaerobic members of the order Bacillales

\begin{tabular}{|c|c|c|c|c|}
\hline Characteristics & AHT28 & $\begin{array}{l}\text { Anaerobacillus } \\
\text { arseniciselenatis }^{\mathrm{a}}\end{array}$ & Anaerobacillus macyae ${ }^{\mathrm{b}}$ & Bacillus selenitireducens ${ }^{\mathrm{a}, \mathrm{c}}$ \\
\hline Cell morphology & $\begin{array}{l}\text { Curved motile rods, } \\
\text { endospores }\end{array}$ & Nonmotile rods, endospores & Motile rods, endospores & Nonmotile rods \\
\hline Fermentation & - & Fructose & - & Glucose, fructose, starch \\
\hline Anaerobic respiration with & $\begin{array}{l}\text { Sulfur, thiosulfate, } \\
\text { arsenate }\end{array}$ & $\begin{array}{l}\text { Arsenate, selenate, } \mathrm{Fe}^{3+}, \\
\text { fumarate, nitrate }\end{array}$ & Arsenate, nitrate & $\begin{array}{l}\mathrm{O}_{2} \text {, arsenate, selenite, nitrate, } \\
\text { fumarate, TMAO }\end{array}$ \\
\hline $\begin{array}{l}\text { Electron donors for } \\
\text { anaerobic respiration }\end{array}$ & $\begin{array}{l}\mathrm{H}_{2} \text {, formate, } \\
\text { pyruvate, lactate }\end{array}$ & $\begin{array}{l}\text { Lactate, citrate, malate, } \\
\text { fructose }\end{array}$ & $\begin{array}{l}\mathrm{H}_{2} \text {, acetate, pyruvate, } \\
\text { succinate, lactate }\end{array}$ & Lactate, pyruvate, glucose \\
\hline Catalase & - & + & + & + \\
\hline DNA G $+\mathrm{C} \mathrm{mol} \%$ & 39.1 & 40.0 & 37.0 & 49.0 \\
\hline PH range (optimum) & $8.5-10.9(10.2)$ & $7.0-10.2(9.8)$ & Neutrophilic & $8.0-10.2(9.0)$ \\
\hline Salt range $\left(\mathrm{M} \mathrm{Na}^{+}\right)$ & $0.2-2.5$ & $0.2-2.0$ & $0-0.5$ & $0.2-3.7$ \\
\hline Habitat & Soda lakes & Soda lakes & Gold mine & Soda lakes \\
\hline
\end{tabular}

\footnotetext{
${ }^{a}$ Switzer Blum et al. (1998)

b Santini et al. (2004)

${ }^{c}$ B. selenitireducens is a member of the family Bacillacea-1 (see Fig. 2)
}

carbonate-based medium at initial pH 10, strain AHT28 was able to grow up to $2 \mathrm{M}$ total $\mathrm{Na}^{+}$with an optimum at 0.6-0.8 M, while the resting cells remained active up to $2.5 \mathrm{M}$ (Fig. 5b). According to these data strain AHT28 can be characterized as moderately salt-tolerant obligate alkaliphile.

Concluding, the Bacillales strain AHT28 isolated from sediments of Siberian soda lakes is a highly active haloalkaliphilic anaerobe specialized on respiration of both elemental sulfur and arsenate. Phenotypically, it differs significantly from the known anaerobic representatives of the order Bacillales (Table 3) representing a first example with such catabolism within this large bacterial phylum. Together with its distinct phylogenetic position, the overall difference warrants proposal of strain AHT28 as a novel genus and species Desulfuribacillus alkaliarsenatis within the order Bacillales but with an uncertain family affiliation.

Acknowledgments This work was supported by RFBR (10-0400152) to DS and by Ministry of Education and Science of Russian Federation (16.552.11.7035) within the frame work of the Federal Program "Priority research in development of the science and technology potential of Russia in 2007-2013" to MS.

Open Access This article is distributed under the terms of the Creative Commons Attribution License which permits any use, distribution, and reproduction in any medium, provided the original author(s) and the source are credited.

\section{Appendix 1}

\section{Description of Desulfuribacillus gen. nov.}

(De.sul.fu.ri.bacil'lus. L. pref. de-, from; L.n. sulfur, sulfur; L. masc.n. bacillus, a rod; N. L. masc n. Desulfuribacillus a sulfur-reducing rod.)
Low GC Gram-positive rod. Obligately anaerobic with respiratory metabolism. Use simple electron donors such as hydrogen and low molecular weight organic acids as electron donors and sulfur and arsenic compounds as electron acceptors. Do not grow autotrophically. Obligately alkaliphilic and moderately salt tolerant. Belongs to the order Bacillales. Habitats-soda lakes. The type species is Desulfuribacillus alkaliarsenatis.

\section{Appendix 2}

Description of Desulfuribacillus alkaliarsenatis sp. nov.

(al.ka.li.ar.sena'tis N.L. n. alkali soda ash; N.L. gen. n. arsenatis, of arsenate, referring to the ability of the organism to reduce arsenate to arsenite; N.L. adj. alkaliarsenatis reducing arsenate at alkaline conditions.)

Cells are rod-shaped, $0.4 \times 2-7 \mu \mathrm{m}$, motile by several peritrichous flagella. Gram-positive, forming terminal round endospores. Strictly anaerobic, with respiratory catabolism, using elemental sulfur, thiosulfate and arsenate as electron acceptors. Sulfur is reduced to sulfide through polysulfide, thiosulfate is reduced incompletely to sulfide and sulfite and arsenate is reduced to arsenite. Grows lithoheterotrophically with hydrogen and formate in the presence of sulfur, thiosulfate and arsenate and heterotrophically with lactate and pyruvate in presence of arsenate. Obligately alkaliphilic with a $\mathrm{pH}$ range for growth between 8.5 and 10.6 and an optimum around 10 and moderately salt tolerant with a range from 0.2 to $2.5 \mathrm{M} \mathrm{Na}^{+}$(optimum at $0.6-0.8 \mathrm{M}$ ). Mesophilic, with a maximum temperature for growth at $43{ }^{\circ} \mathrm{C}$ and an optimum at $35{ }^{\circ} \mathrm{C}$. The predominant fatty acids in the polar membrane lipids include 
$16: 0,16: 1 \omega 7 \mathrm{c}$ and $18: 1 \omega 7 \mathrm{c}$. The dominant respiratory lipoquinone is MK-7. meso-DAP is present in the murein. The $\mathrm{G}+\mathrm{C}$ content of the genomic DNA is $39.1 \mathrm{~mol} \%$ $\left(\mathrm{T}_{\mathrm{m}}\right)$. The type strain is AHT28 ${ }^{\mathrm{T}}\left(\mathrm{DSM} 24608^{\mathrm{T}}=\mathrm{UNI}-\right.$ QEM U855 ${ }^{\mathrm{T}}$ ). Isolated from sediments of soda lakes in southwestern Siberia. The GenBank 16S rRNA gene sequence accession number of the type strain is HM046584.

\section{References}

Collins MD (1985) Analysis of isoprenoid quinones. Methods Microbiol 18:329-363

Felsenstein J (1993) PHYLIP (phylogeny inference package), version 3.53c. Department of Genetics, University of Washington, Seattle, USA

Hedderich R, Klimmek O, Kroëger A, Dirmeier R, Keller M, Stetter KO (1999) Anaerobic respiration with elemental sulfur and with disulfides. FEMS Microbiol Rev 22:353-381

Hollibaugh JT, Budinoff C, Hollibaugh RA, Ransom B, Bano N (2006) Sulfide oxidation coupled to arsenate reduction by a diverse microbial community in a soda lake. Appl Environ Microbiol 72:2043-2049

Kämpfer P (2002) Whole-cell fatty acid analysis in the systematics of Bacillus and related genera. In: Berkley R, Heyndrickx M, Logan N, De Vos P (eds) Applications and systematics of Bacillus and relatives. Blackwell Science, Oxford, pp 271-299

Kulp TR, Hoeft SE, Miller LG, Saltikov C, Murphy JN, Han S, Lanoil B, Oremland RS (2006) Dissimilatory arsenate and sulfate reduction in sediments of two hypersaline, arsenic-rich soda lakes: Mono and Searles Lakes, California. Appl Environ Microbiol 72:6514-6526

Kulp TR, Han S, Saltikov CV, Lanoil BD, Zargar K, Oremland RS (2007) Effects of imposed salinity gradients on dissimilatory arsenate reduction, sulfate reduction, and other microbial processes in sediments from two California soda lakes. Appl Environ Microbiol 73:5130-5137

Lane DJ (1991) 16S/23S rRNA sequencing. In: Stackebrandt E, Goodfellow M (eds) Nucleic acid techniques in bacterial systematics. Wiley, Chichester, pp 115-177

Lloyd JR, Oremland RS (2006) Microbial transformation of arsenic in the environment: from soda lakes to aquifers. Elements 2:85-90

Lowry OH, Rosebrough NJ, Farr AL, Randall RJ (1951) Protein measurement with Folin phenol reagent. J Biol Chem 193:265-275

Ludwig F, Schleifer K-H, Whitman WB (2009) Revised road-map to the phylum Firmicutes. In: De Vos P, Garrity GM, Jones D, Krieg NR, Ludwig W, Rainey FA, Schleifer K-H, Whitman WB (eds) Bergey's manual of systematic bacteriology, V.3, the Firmicutes. Springer, Dordrecht, p 3

Malasarn D, Saltikov CW, Campbell KM, Santini JM, Hering JG, Newman DK (2004) arrA is a reliable marker for As(V)respiration. Science 306:455

Marmur J (1961) A procedure for isolation of DNA from microorganisms. J Mol Biol 3:208-214
Marmur J, Doty P (1962) Determination of the base composition of deoxyribonucleic acid from microorganisms. J Mol Biol 5:109-118

Pfennig N, Lippert KD (1966) Über das Vitamin $\mathrm{B}_{12}$-Bedürfnis phototropher Schwefelbakterien. Arch Mikrobiol 55:245-256

Plugge CM (2005) Anoxic media design, preparation, and considerations. Methods Enzymol 397:3-16

Santini JM, Streimann ICA, van den Hoven RN (2004) Bacillus macyae sp. nov., an arsenate-respiring bacterium isolated from an Australian gold mine. Int J Syst Evol Microbiol 54:2241-2244

Schleifer KH, Kandler O (1972) Peptidoglycan types of bacterial cell walls and their taxonomic implications. Bacteriol Rev 36:407-477

Sörbo B (1957) A colorimetric determination of thiosulfate. Biochim Biophys Acta 23:412-416

Sorokin DY, Muyzer G (2010) Desulfurispira natronophila gen. nov. sp. nov.: an obligately anaerobic dissimilatory sulfur-reducing bacterium from soda lakes. Extremophiles 14:349-355

Sorokin DY, Rusanov II, Pimenov NV, Tourova TP, Abbas B, Muyzer G (2010) Sulfidogenesis at extremely haloalkaline conditions in soda lakes of Kulunda Steppe (Altai, Russia). FEMS Microbiol Ecol 73:278-290

Sorokin DY, Detkova EN, Muyzer G (2011) Sulfur-dependent respiration at extremely haloalkaline conditions in soda lake "acetogens" and the description of Natroniella sulfidigena sp. nov. FEMS Microbiol Lett 319:88-95

Streshinskaya GM, Naumova IB, Panina L (1979) Cell wall composition of Streptomyces chrysomallus producing the antibiotic aurantin. Microbiology (Moscow, English Translation) 48:814-819

Switzer Blum J, Bindi AB, Buzzelli J, Stolz JF, Oremland RS (1998) Bacillus arsenicoselenatis, sp. nov., and Bacillus selenitireducens, sp. nov.: two haloalkaliphiles from Mono Lake, California that respire oxyanions of selenium and arsenic. Arch Microbiol 171:19-30

Switzer Blum J, Han S, Lanoil B, Witte B, Saltikov C, Tabita FR, Langley S, Beveridge TJ, Jahnke L, Oremland RS (2009) Ecophysiology of "Halarsenatibacter silvermanii" strain SLAS1T, gen. nov., sp. nov., a facultative Chemoautotrophic arsenate respirer from salt-saturated Searles Lake, California. Appl Environ Microbiol 75:1950-1960

Trüper HG, Schlegel HG (1964) Sulfur metabolism in Thiorhodaceae. 1. Quantitative measurements on growing cells of Chromatium okenii. Antonie Van Leeuwenhoek 30:225-238

van de Peer Y, de Wachter R (1994) TREECON for Windows: a software package for the construction and drawing of evolutionary trees for the Microsoft Windows environment. Comput Appl Biosci 10:569-570

Zavarzina DG, Tourova TP, Kolganova TV, Boulygina ES, Zhilina TN (2009) Description of Anaerobacillus alkalilacustre gen. nov., sp. nov.- strictly anaerobic diazotrophic Bacillus isolated from soda lake and transfer of Bacillus arseniciselenatis, Bacillus macyae, and Bacillus alkalidiazotrophicus to Anaerobacillus as the new combinations A. arseniciselenatis comb. nov., A. macyae comb. nov., and A. alkalidiazotrophicus comb. nov. Microbiology (Moscow, English translation) 78:723-731

Zhilina TN, Zavarzin GA, Rainey FA, Pikuta EN, Osipov GA, Kostrikina NA (1997) Desulfonatronovibrio hydrogenovorans gen. nov., sp. nov., an alkaliphilic, sulfate-reducing bacterium. Int J Syst Bacteriol 47:144-149 